\title{
TANÁRJELÖLTEK PÁLYAKÉPE, KÉPZÉSSEL VALÓ ELÉGEDETTSÉGÜK ÉS NEHÉZSÉGEIK
}

\author{
N. KOLlár KATALIN \\ az Eötvös Loránd Tudományegyetem Pedagógiai és Pszichológiai Kar Pszichológiai Intézet \\ Iskolapszichológia Tanszékének \\ egyetemi docense \\ kollar.katalin@ppk.elte.hu
}

\begin{abstract}
Tanulmányunkban gyakorló pedagógusok és az ELTE tanárképzésében frissen végzett hallgatók körében végzett kérdőíves vizsgáltról számolunk be, melyet a pedagógus pálya fö feladataival, a végzéséhez szükséges személyiségjellemzökkel és a pedagógusképzéssel kapcsolatban végeztünk. A vizsgálatban 275 pedagógus és 144 hallgató válaszait hasonlitottuk össze. A pedagógusvizsgálat eredményeiröl a Pedagógusképzés 2008. 4. számában részletesen beszámoltunk. Ebben a tanulmányban a két minta összehasonlitásával mutatjuk be a tanárképzés eddigi eredményeit és az elöttünk álló feladatokat. A pedagógusok és a pályakezdök jellemzöen hasonlóan itélik meg a pedagógus pálya fö feladatait, az ehhez szükséges tulajdonságokat, és egyetértenek abban is, hogy felkészülésük hiányosságai elsősorban a sajátos bánásmódot igénylö, magatartási problémás, átlag alatt, illetve felett teljesitö tanulókkal való bánásmód területén van. A frissen végzettek magasabbra értékelik a tanitási gyakorlat és az egyetemi szemináriumok hasznosságát. A pályakezdők elvárásai a képzéssel kapcsolatban hasonlóak, mint a pedagógusoké, ahol eltérést tapasztaltunk, ott a pályakezdők elvárásai magasabbak. Ennek ellenére az ELTE hallgatói elégedettebbek a saját képzésükkel, a szakmai felkészültség kivételével minden területen jobbnak tartják a képzésüket, mint a pályán levö pedagógusok. A szakmai felkészültségüket és a módszertani tudást tartják a pedagógiai-pszichológiai elméleti felkészültségük mellett a legmegalapozottabbaknak, ugyanakkor a képzés nyújtotta szakmai tudásukat gyengébbnek itélik, mint a pályán levök. Az eredmények visszajelzésül szolgálnak a képzés erösségeiről és kijelölik a tanárképzés elött álló feladatokat, az erősitendő területeket az átalakuló pedagógusképzésben.
\end{abstract}

A jelen kutatási beszámoló szerves folytatása a Pedagógusképzés 2008. 4. számában megjelent, a Pedagógusok pályaképe, a képzéssel való elégedettsége és nehézségei címú tanulmányunknak. Míg a korábbi írásunkban a gyakorló pedagógusok kérdőíveinek adatait dolgoztuk fel, most a nappali tagozaton frissen végzett hallgatók ${ }^{1}$ véleményét mutatjuk be, összehasonlítva a már pályán levő pedagógusok véleményével.

\footnotetext{
${ }^{1}$ Az általunk kérdezett pályakezdők jogilag már nem diákok, az ábrákon és az elemzés során hallgatókként nevezzük meg őket, mivel a kikérdezéskor munkába lépés előtt voltak, hiszen csak néhány nappal előbb ért véget hallgatói életük.
} 


\section{Vizsgálatok a tanárképzéssel kapcsolatban}

A pedagógusképzés hatékonyságával kapcsolatban kevés közvetlen vizsgálatra tudunk támaszkodni. Az itt bemutatásra kerülő vizsgálatok határozott korlátja, hogy az érintettek véleményét, attitüdjeit vizsgálja, a tényleges beválás és a képzés elemei közti kapcsolatot azonban nem. A kevés számú hatásvizsgálat is csupán egy-egy képzési elem, például egy tanfolyam vagy kurzus, hallgatókra gyakorolt szerepét méri. Ez nem véletlen, mivel a képzés hatékonyságának mérése nagyon komplex feladat, ami a terepen végzett hosszú követéses vizsgálatokkal lenne igazán hatékony. Mégsem nélkülözzük teljesen azokat a vizsgálati eredményeket, amelyek tanulságosak a pedagógusképzés tervezéséhez.

\section{A tanári végzettség szerepe}

Az egyik vizsgálati kérdés az - első pillanatban talán meglepő módon -, hogy hatékonyabban végzik-e a pedagógusok munkájukat tanári végzettség birtokában, mint a nélkül. Sarkítva, úgy is kérdezhetnénk, kell-e diploma ahhoz, hogy valaki jól tanítson.

Darling-Hammond és munkatársai (Darling-Hammond, Berry, Thoeson, 2001) a pedagógus végleges minősítésének meglétét és a diákok eredményességének kapcsolatát vizsgálta. Tanulmányuk kiindulópontja Goldhaber és Brewer egy évvel korábban megjelent cikke volt, melyben a szerzők azt az állítást fogalmazták meg, hogy míg a matematika és kisebb mértékben a természettudományok oktatása terén is a tanítványok eredményességét rontja a tanári végzettség hiánya (emergency certification), addig általában vizsgálva, a standard képesítéssel nem rendelkezők hatékonysága nem maradt el a képesítettekétől. Ezért a képesítő vizsgát nem tartják a szerzők feltétlenül szükségesnek. Darling-Hammond és munkatársai módszertanilag kritizálták a megállapításokat. Az adatok újraelemzésével arra a megállapításra jutottak, hogy a kivételesen vagy ideiglenesen müködési engedélyt kapott tanárok a képesítéssel rendelkezőkkel közel azonos szintü végzettséggel rendelkeznek, és hogy igazolható az összefüggés a tanárok általános végzettségi szintje és a tanulók eredményei között.

Ez a két tanulmány az amerikai tanári képesítési rendszer gyakorlatának hatékonyságát vizsgálja, ahol a tanári képesítővizsga és a föiskolai vagy egyetemi szintủ diploma megszerzése gyakran szétválik. Az a megállapításuk azonban, hogy a végzettség - és ennek hátterében a szakmai tudás, mint a felkészültség egyik eleme, különösen a természettudományok területén - összefügg egymással, közvetlenül kapcsolódik a magyarországi tanárképzés körüli, a bolognai képzés bevezetésével kibontakozott vitákhoz. Főként a természettudományos tárgyakkal, mint második szakkal (minor szak) kapcsolatban fogalmazódik meg az az aggály, hogy a hallgatók tudományos felkészültsége nem lesz elegendő. Úgy gondoljuk, a későbbiekben 
ezzel kapcsolatban két szempontot érdemes lenne szisztematikus vizsgálat tárgyává tenni. Egyrészt azt, hogy melyek azok témák egy-egy szakon belül, amelyek elsajátítása, egy középiskolai tanár számára, nagy figyelmet érdemes fordítani azért, mert ezeket a témákat maga is oktatni fogja, és melyek a tanári pályán kevéssé használható, elsősorban a szemléletformálás miatt hasznos területei a tudományágnak? Vannak-e olyan, a kutatóképzésben preferált témák, amelyeket a középiskolai oktatás nem képes érintőlegesen sem befogadni? Másrészről célszerủ lenne az új képzés hatékonyságát vizsgálni, és ennek eredményeit visszaforgatni a képzés fejlesztésébe.

\section{A képzéssel való elégedettség és a pályára való felkészítés tartalmi elemei}

Nagy-Britanniában a Training and Development Agency for Schools minden évben lefolytat egy vizsgálatot a frissen végzett tanárok körében a képzéssel kapcsolatos elégedettségükről (www. tda.gov.uk). 2007-ben a 2005-2006-ban végzett tanároknak, összesen 31000 pedagógusnak küldték ki a kérdőíveket, és 11000 válasz alapján reprezentatív képet kaptak a képzésröl. Kérdésfeltevésük négy kérdéskörre irányult:

- a képzéssel való elégedettség;

- milyen pályakezdést segítő képzésben vettek részt a megkérdezettek, és ezek mennyiben járultak hozzá a felkészülésükhöz, hogy elkezdjenek tanítani;

- jelenlegi alkalmazásuk körülményei;

- esetleges saját nehézségek testi fogyatékosság miatt, ezzel kapcsolatos hozzáállás.

A pedagógusképzés hatékonysága szempontjából számunkra az első kérdéskörrel kapcsolatos eredmények a leginkább informatívak, ezért ezeket ismertetjük. A kérdőívekre válaszolók többsége első szakképzettséget szerzett, 25 év alatti nő volt. A képzés színvonalával a válaszolók nagymértékben meg voltak elégedve: 88 százalékuk jó vagy nagyon jó színvonalúnak tartotta a tanárképzést (négyfokú skálán 3, illetve 4). Ez az elégedettség egyaránt vonatkozott a hallgatóként kapott visszajelzésekre, az értékelésre a képzés során, az osztálytermi munkára való felkészülésükre és a tanári képesítés megszerzésének elősegítésére. A képzéssel elégedettek csoportját érdemes tovább differenciálni: 34 százaléka volt teljes mértékben elégedett, és 54 százalékuk adott ,jó” minősítést. Az elmúlt évekhez viszonyítva a válaszolók véleménye javuló tendenciát mutat, de alapvetően a gyenge minősítést adók százaléka csökken, a nagyon elégedettek aránya változatlan.

Az osztálytermi hatékony viselkedés megtanulásában évről évre javuló tendencia figyelhető meg, míg 2003-ban a válaszolók 59 százaléka minősítette a képzését, ebből a szempontból, jónak vagy nagyon jónak, addig 2007-ben ez az arány 71 százalék volt. A pályakezdéshez a hatékony tapasztalatok közt évről évre egyre többen említik a különböző tanítási módszereket, amelyek segítik a diákok hatéko- 
nyabb tanulását, a tanulás eredményességének mérését és visszajelzését, a kollegákkal való team-munkát, a gyermekek biztonságának és jóllétének törvényes biztosítását, a speciális szükségletü és az átlagtól eltérő képességü tanulók tanítását, a különböző etnikai csoportba tartozó és a nem angol anyanyelvủ tanulók tanítását. Ugyancsak javulás észlelhető a tanárjelöltek szakmai felkészültségében és az információs, kommunikációs technológia alkalmazásában.

Belgiumban szintén a tanárképzésben frissen végzett hallgatók körében végeztek kérdőíves vizsgálatot (Rots et al., 2007). 209 végzett pedagógusból 62,2 százalék helyezkedett el pedagógusként, 37,8 százalék tanári végzettsége ellenére más munkahelyet választott. A vizsgálat alapkérdése a tanári pályán való elhelyezkedés, a képzés jellemzői, a tanításba való betanulás és a pálya iránti elköteleződés összefüggése volt. Eredményeik szerint a pálya iránti elköteleződés alapvető ahhoz, hogy a végzettek valóban a tanári pályára lépjenek. Jelentős tényező ebben még a mentortanár értékelő visszajelzése is. A személyiségváltozók közül a személyes hatékonyság és a szakmai érdeklődés iránya mutatott összefüggést a tanári foglalkozás választásával. A vizsgálat meglepő eredménye, hogy a magukat felkészültebbnek érzők kevésbé vállalnak tanári állást! A szakképzettség szerint az óvó- és tanító szakosok, akiknél erősebb a pedagógiai-didaktikai képzés és kevésbé hangsúlyos a szakmai tárgyak oktatása, nagyobb valószínüséggel helyezkednek el pedagógusi munkakörben.

A tanárképzés szempontjából tanulságokat szolgáltató szakirodalom keresése közben a böség zavarát és a vizsgálatok hiányát egyaránt tapasztalhatjuk. Egyrészt bizonyos témakörökben bőséges és informatív anyag áll rendelkezésre, ilyen kérdéskör például az általunk nem részletezett tanári pálya szociológiai jellemzői és a pedagógusok életmódja, vagy a tanár-diák kapcsolat. Kevés célzott vizsgálatot találunk azonban a tanári képzés hatékonyságával kapcsolatban. Egyes programok hatásvizsgálatán túl leggyakrabban a pályakezdéshez kapcsolódó kérdéskörökkel: - Milyen mértékben felkészültek a pedagógusok a képzést követően? - Mekkora motivációval lépnek a munkaerőpiacra a pedagógusok? Vagy a szükebb szakterületekhez kapcsolódó módszertani kérdésekkel találkozunk.

\section{Vélemények és elvárások a tanári pályával kapcsolatban}

Suplicz István (2007) vizsgálatában középiskolás diákokat, tanárképzésben részt vevő föiskolai hallgatókat és öt éve végzett mérnöktanárokat kérdezett legjobb és legrosszabb tanáraik jellemzőiről. A válaszokat öt kategóriába sorolta. Eredményei szerint a tanári sikeresség szempontjából az érzelmi elfogadás, a pedagógiai erények és a személyes tulajdonságok a fontosak. Ezen belül a középiskolások válaszaiban gyakrabban jelennek meg az érzelmi elfogadás és a pedagógiai erények és hibák kategória, míg a tanárjelöltek és végzettek a személyiségtulajdonságokat említik nagyobb gyakorisággal. A szakmai tudás, ill. ennek hiánya mindegyik almintában 
kis jelentőségü. A meghatározó tulajdonságokat a válaszolók inkább tartották személyiségfüggőeknek, mint tanulhatóaknak.

Egy nyolc európai országra kiterjedt kérdőíves vizsgálatban (Margiotta, 2010) tanár szakos egyetemi hallgatók véleményét hasonlították össze a tényleges képzés jellemzői és a saját elvárásaik tekintetében. A képzések közös jellemzője, hogy az iskolai gyakorlati tapasztalatokat és a tantárgyi tudást egyaránt hangsúlyozzák mind a jelenlegi képzésben, mind az elvárások szintjén. A nyolc egyetem, ill. föiskola által nyújtott képzés közt jelentős eltéréseket találtak a szaktudás közvetítése, az elméleti és gyakorlati tudás összekapcsolása, a pedagógiai-pszichológiai és módszertani tudás mértéke, a módszertani jártasság, a személyes fejlesztés elősegítése, a gyakorlati képzés színvonala, az idegen nyelv elsajátítása és a disszertáció jelentősége szempontjából a képzés során. A magyar hallgatók más országok diákjaihoz képest fontosabbnak tartják a szaktudást és a pedagógiai-pszichológiai és módszertani tudást, nagyra értékelik az iskolai gyakorlatot, viszont kevésbé tarják fontosnak az elméleti és gyakorlati tudás összekapcsolását. Egyöntetü a hallgatók véleménye abban, hogy az iskolai gyakorlatot kiemelten fontosnak tartják, és nagyfokú hasonlóság van a véleményükben arról, hogy minden tekintetben többet várnak a képzéstől, mint amennyit a jelenlegi képzés nyújt.

\section{Vizsgálat a tanárjelöltek véleményéről}

A tanári pálya feladatairól, a pedagógusi munkához szükséges tulajdonságokról és kompetenciákról, valamint a tanárképzés hatékonyságáról, mint ahogyan arról a korábban már említett tanulmányban beszámoltunk, megkérdeztük a már pályán levő pedagógusokat (a jelen tanulmányban 275 pedagógus adatait dolgoztuk fel), és utóbb megkérdeztük az ELTE tanárképzésében részt vett hallgatókat is (144fö). A felmérést 2007. és 2008. július-augusztus folyamán, a júniusban képesítő vizsgát tett hallgatók körében végeztük. A hallgatók még a bolognai képzés bevezetése elött, de már a 111/1997-es kormányrendelet által elöírt követelmények szerint végezték a tanári tanulmányaikat.

A hallgatókat e-mailben kerestük meg közvetlenül a képesítő vizsga után, és e-mailben is kaptuk vissza a kitöltött kérdőíveket. A visszaküldés aránya 12 százalék. Ez az arány az értelmezés terén óvatosságra int bennünket. Az önkéntes kitöltés, a kérdőív hossza és a vizsgálat időpontja némileg indokolja az alacsony kitöltési hajlandóságot.

A kitöltők aránya miatt felmerül a kérdés, hogy a válaszolók jellemezhetőek-e valamilyen közös motivációval, például elkötelezettebbek vagy éppen elégedetlenebbek az átlagosnál. A válaszokban erre vonatkozóan több információ is rendelkezésünkre áll. Egyrészt a kitöltők gondosan dolgoztak, elenyésző a kimaradt válaszok aránya. A 144 válaszoló többsége a nyitott kérdésre is választ adott. A nyitott kérdés a tanárképzésből hiányzó elemek mellett globális vélemény kifejtésére is te- 
ret adott. Másik támpontunk, hogy a nyitott kérdés alapján a minta tartalmilag mennyire kiegyensúlyozott, az elégedetlenek vagy éppen a nagyon elégedettek válaszoltak-e a kérdéseinkre (1. táblázat).

1. táblázat: A tanárképzéssel kapcsolatos vélemények és javaslatok tartalmi megoszlása

\begin{tabular}{|l|c|c|}
\hline \multicolumn{1}{|c|}{ Válaszkategóriák } & Válaszolók száma & Relatív gyakoriság (\%) \\
\hline csak hiányokat említ & 31 & 21,5 \\
\hline csak negatívumok & 25 & 17,4 \\
\hline csak pozitívumok & 3 & 2,0 \\
\hline pozitívumok és negatívumok & 40 & 27,8 \\
\hline nem adott szöveges választ & 45 & 31,3 \\
\hline Összesen: & 144 & $100 \%$ \\
\hline
\end{tabular}

A tartalom alapján kiegyensúlyozott képet kaptunk, a válaszolók kétharmada adott szöveges választ, egynegyedük csak további ötleteket, hiányzó elemeket említett, túlnyomó többségük több gyakorlati elemet igényelt. Csupán 17,4 százalékuk fogalmazott meg kifejezetten negatív véleményt és elhanyagolhatóan kevés a csak pozitívumokat említők száma. Ezek alapján a minta motivációs szempontból nem egyoldalú, és az 1. táblázat alapján kizárhatjuk, hogy a válaszolók az elégedett hallgatókat képviselnék.

Elégedetlenek lehetünk viszont a minta szakos összetételével. Bár a kérdőívet minden hallgatóhoz eljuttattuk, mégis a humán szakosok a tényleges szakos arányokat messze meghaladó mértékben túlreprezentáltak. A válaszolók 89,2 százalékban a humán szakosok közül kerültek ki, vegyes, humán és reál szakos a válaszolók 5,0 százaléka. A természettudományi területeket mindössze a válaszadók 1,5 százaléka képviselte.

A diákok véleményét a pedagógus mintával összehasonlítva mutatjuk be, mivel a válaszok alapvető tartalmukban nem különböznek a két mintában. A tanulságok elsősorban a két minta összehasonlításából adódnak. A tanárok és diákok véleményének összehasonlítására két mintás t próbát végeztünk, ahol a szórások különböztek (F próba értéke szign.), ott a szórásegyezést nem feltételező próbát alkalmaztunk. A táblázatokban ezekben az esetekben ezt az értéket tüntettük fel. ${ }^{2}$

A vizsgálatban arra kerestünk választ, hogy az ELTE tanárképzésében részt vevő hallgatók és a már pályán levő pedagógusok közt van-e különbség a tekintetben, hogy hogyan vélekednek a pedagóguspálya feladatairól, az ehhez szükséges

${ }^{2}$ Az ábrákon és táblázatokban a $\mathrm{p}<0,10$ értéket ${ }^{+}$jellel, $\mathrm{p}<0,05-\mathrm{t} *, \mathrm{p}<0,01 * *, \mathrm{p}<0,001 * * *$ jellel jelöltük. 
tulajdonságaik meglétéről, fejleszthetőségéről és magáról a képzésről, valamint, hogy a képzés mennyiben és milyen eszközökkel segítette a pályára való felkészülésüket. Az alkalmazott kérdőívet a Pedagógusképzés 2008. 4. számában közöltük.

\section{A tanári feladatok fontosságának megítélése}

A pedagógusok és a hallgatók ötfokú skálán ítélték meg különféle tanári feladatok fontosságát (lásd 1. ábra).

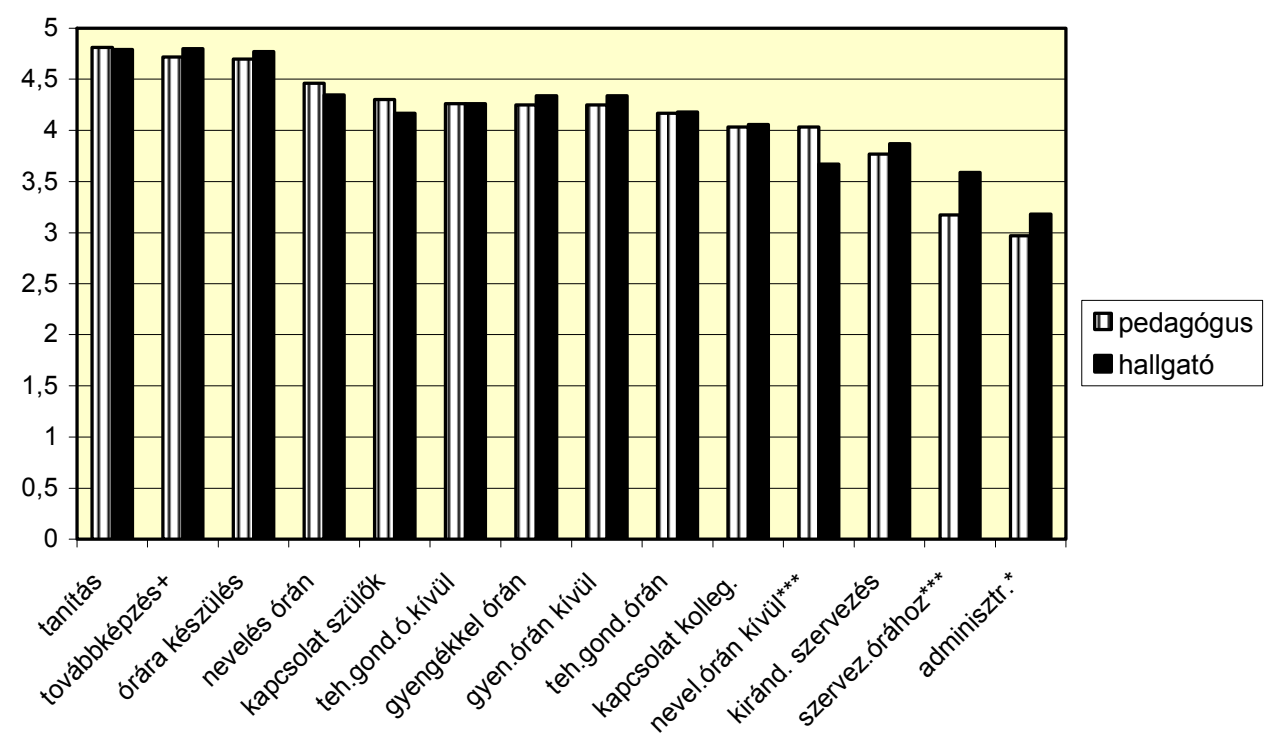

1. ábra: Tanári feladatok fontossága a pedagógusok és a hallgatók szerint

A diákok és a gyakorló pedagógusok alapvetően azonosan látták a feladatok fontosságát. Ez a képzésre vonatkozóan pozitív eredmény, a hallgatók reálisan, a gyakorlati feladatok súlyát felmérve kezdik meg a pedagógus pályát. Ez persze nem jelenti azt, hogy a tényleges kompetenciák tekintetében is felkészültek, vagy annak érzik magukat, ezt a továbbiakban vizsgáljuk majd meg. Másrészről azonban bizonyos vonatkozásokban mérhető különbségeket találtunk a két csoport közt. A feladatok fontosságának megítélését kétmintás t próbával hasonlítottuk össze (lásd 2. táblázat). 
2. táblázat: Egyes tanári feladatok fontossága a pedagógusok és a hallgatók szerint

\begin{tabular}{|l|c|c|c|c|c|}
\hline \multicolumn{1}{|c|}{ Tanári feladatok } & $F$ & Szig. & $t$ & $\begin{array}{c}\text { Szig. } \\
\text { (2-oldalú) }\end{array}$ & $\begin{array}{c}\text { Átlag- } \\
\text { különbség }\end{array}$ \\
\hline nevelés órán kívü1*** & 1,867 &, 173 & 3,498 &, 001 &, 12 \\
\hline adminisztráció* & 3,365 &, 067 & $-2,048$ &, 041 &,- 22 \\
\hline szervezés órához*** & 3,260 &, 072 & $-3,983$ &, 000 &,- 42 \\
\hline továbbképzés $(\mathrm{p}<0,10)$ & & $\mathrm{P}<0$, & $-1,787$ &, 075 & $-0,0862$ \\
\hline
\end{tabular}

Az órán kívüli nevelés fontosságát a pedagógusokhoz képest a frissen végzettek alábecsülték. Ugyanakkor fontosabbnak tartották az órához kapcsolódó szervezést és az adminisztratív munkát is. Tendencia szinten a továbbképzéseket is jobban hangsúlyozták, ami összefügghet a pályakezdőknek azzal, a későbbiek során bemutatásra kerülő érzésével, hogy számos területen felkészületlenek tartják magukat. Összességében azt látjuk, hogy csupán árnyalatnyi különbség van a pedagógusok és a pályakezdők hozzáállása közt, a pályakezdőket jobban foglalkoztatják az órát előkészítő szervezés problémái, és a pályán levőknél jobban hisznek az adminisztráció hasznában, azonban az adminisztráció náluk is a fontossági rangsor utolsó helyén áll.

\section{Tulajdonságok fontossága a pedagógus pályán}

A tulajdonságokat a pedagógusok véleménye alapján állítottuk fontossági sorrendbe, és a 2. ábrán azt mutatjuk be, hogy hozzájuk képest a hallgatók hogyan ítélik meg a tulajdonságok jelentőségét. A tulajdonságok megítélésénél is azt láthatjuk, amit korábban a feladatkörök esetén, hogy a hallgatók véleménye alapvetően hasonlít a pályán levőkéhez.

A hitelesség mindkét csoport szerint egyaránt kiemelkedő jelentőségü. Az empátiának a hallgatók kevésbé tulajdonítanak jelentőséget, ami azért érdekes eredmény, mert ugyanakkor három olyan szempont van, amit ők jobban hangsúlyoznak, és amelyek valamilyen módon az empatikus viselkedésre utalnak: a sérültek elfogadása, a kultúrákra való nyitottság és a szociális alkalmazkodás. Úgy véljük, mindháromban a problémakör tudatosabb kezelését láthatjuk. Nem gondoljuk, hogy ez önmagában kielégítő magyarázat arra, hogy az empátiát a hallgatók kevésbé hangsúlyozzák, de felveti annak lehetőségét, hogy az „általános” pozitív hozzáállást sok esetben tudatos problémakezelés válthatja fel.

A többi tulajdonság, amelyeket a hallgatók fontosabbnak tartottak a pályakezdés kihívásaiként is értelmezhetőek: a határozottság, a kezdeményező készség, a vezetési képesség, a gyerekekkel és gyermekcsoportokkal való bánásmód, a kreativitás és a gyors reagálás összefüggésbe hozhatóak a helyzetek váratlanságával, mint várható nehézséggel. 


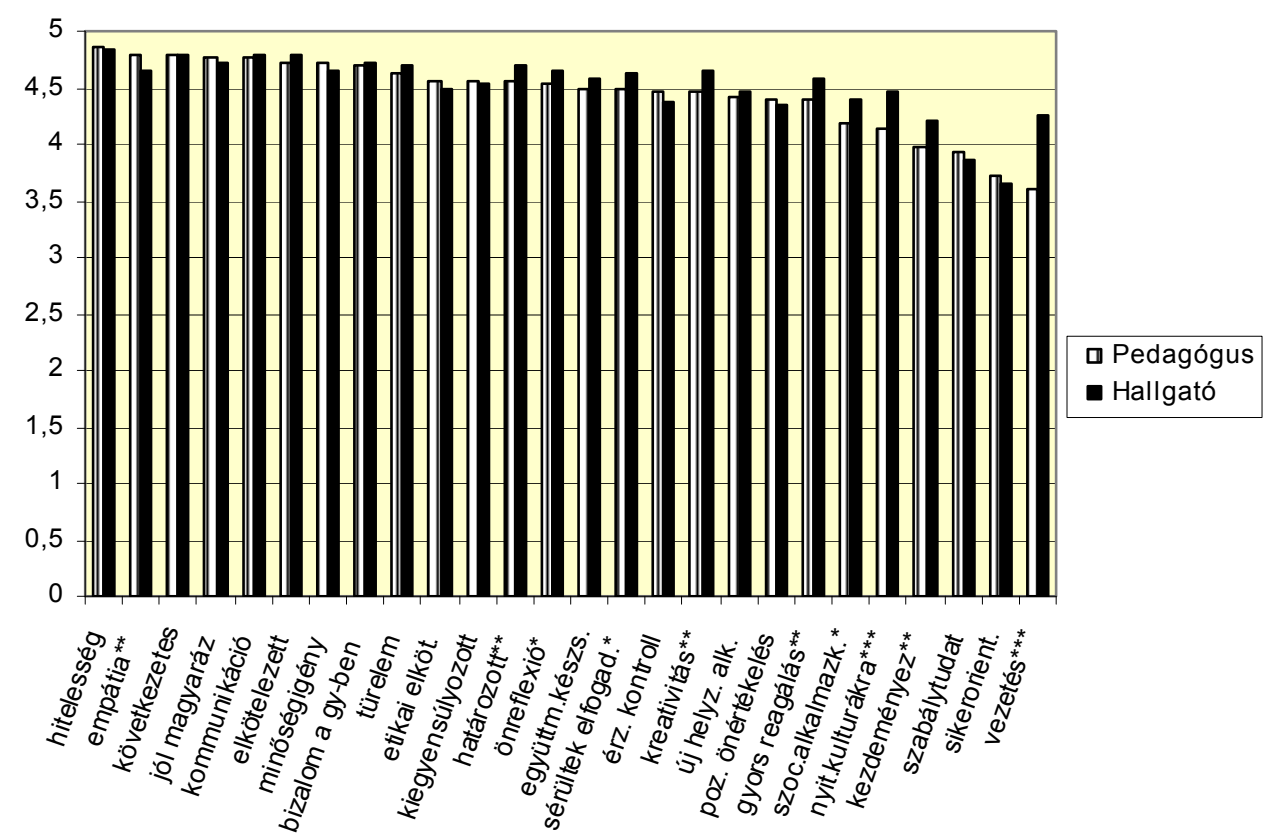

2. ábra: Tulajdonságok fontossága a pedagógusok és a hallgatók szerint

Az önreflexió nagyobb mértékü hangsúlyozása szintén összefügghet a pályakezdéssel, de elképzelhető, hogy a képzés sajátosságai is tükröződnek ebben, tudniillik a 2007-2008-ban végzettek már kötelezően részt vettek önismereti-képességfejlesztő tréningen is. Hogy a képzés mennyiben járul hozzá az önreflexió erősödéséhez, az a bolognai képzésből kikerülő hallgatóknál lesz mérhető, ahol ez az elem még inkább megerősítést nyert ${ }^{3}$. A minták közti különbségeket a 3. táblázatban mutatjuk be.

Összességében a tulajdonságokról azt lehet mondani, hogy mind a pedagógusok, mind a frissen végzett hallgatók véleménye szerint a vizsgált tulajdonságok túlnyomó többsége nagyon fontos a sikeres munkavégzéshez. A hallgatók csoportjára ez fokozottan igaz, ti. a 26 vizsgált tulajdonság közül náluk 17 esetében haladta meg a tulajdonság fontosságának átlaga a 4,5-ös értéket.

\footnotetext{
${ }^{3}$ A legújabb típusú képzésben az első nappali tagozatos évfolyam 2012 januárjában fog végezni.
} 
3. táblázat: Az adott tulajdonságok fontossága a pedagógus pályán a pedagógusok és hallgatók szerint - a két csoport közti szignifikáns különbségek. (Kétmintás t-próba.)

\begin{tabular}{|l|c|c|c|c|c|}
\hline \multicolumn{1}{|c|}{ Tulajdonságok } & $F$ & Szig. & $t$ & $\begin{array}{c}\text { Szig. } \\
\text { (2-oldalú) }\end{array}$ & $\begin{array}{c}\text { Átlag- } \\
\text { különbség }\end{array}$ \\
\hline empátia** & 27,307 &, 000 & 2,730 &, 007 &, 15 \\
\hline határozottság** & 19,698 &, 000 & $-2,886$ &, 004 &,- 16 \\
\hline önreflexió* & 4,641 &, 032 & $-2,147$ &, 033 &,- 13 \\
\hline sérültek elfogadása* & 4,613 &, 032 & $-2,097$ &, 037 &,- 14 \\
\hline kreativitás** & 5,785 &, 017 & $-2,741$ &, 006 &,- 17 \\
\hline gyors reagálás** & 3,158 &, 076 & $-3,011$ &, 003 &,- 20 \\
\hline szoc. alkalmazkodás* & 6,125 &, 014 & $-2,713$ &, 007 &,- 21 \\
\hline nyitott a kulturákra*** &, 142 &, 706 & $-4,288$ &, 000 &,- 32 \\
\hline kezdeményezökészség** & 2,736 &, 099 & $-2,876$ &, 004 &,- 23 \\
\hline vezetés*** & 11,237 &, 001 & $-7,657$ &, 000 &,- 66 \\
\hline
\end{tabular}

\section{A tulajdonságok fejleszthetösége}

A tulajdonságok fejleszthetőségének megítélésében nagyfokú egyetértés van a pedagógusok és diákok közt, a 26 tulajdonságból csak hétben találunk szignifikáns eltérést a két csoport véleménye közt. Mind a hét esetben a hallgatók vélekedtek úgy, hogy a tulajdonságok nagyobb mértékben fejleszthetőek. (4. táblázat)

4. táblázat: Milyen mértékben fejleszthetőek az adott tulajdonságok a pedagógusok és hallgatók szerint? (Kétmintás t-próba)

\begin{tabular}{|c|c|c|c|c|c|}
\hline Tulajdonságok & $F$ & Szig. & $t$ & $\begin{array}{c}\text { Szig. } \\
\text { (2-oldalú) }\end{array}$ & \begin{tabular}{|c|}
$\begin{array}{c}\text { Átlag- } \\
\text { különbség } \\
\text { (ped. hallgató) }\end{array}$ \\
\end{tabular} \\
\hline $\begin{array}{l}\text { új helyzethez való } \\
\text { alkalmazkodás }\end{array}$ & 1,035 &, 310 & $-1,796$ & ,073 &,- 16 \\
\hline $\begin{array}{l}\text { kultúrákra való } \\
\text { nyitottság** }\end{array}$ & 1,014 & 314 & $-2,834$ & ,005 &,- 25 \\
\hline etikai elkötelezettség* &, 128 &, 720 & $-2,291$ &, 022 &,- 24 \\
\hline jól magyarázni tudás ${ }^{+}$ &, 105 & ,746 & $-1,817$ &, 070 &,- 16 \\
\hline együttmüködési készség* & ,639 &, 424 & $-2,449$ &, 015 &,- 21 \\
\hline hitelesség* & 2,239 &, 135 & $-1,988$ & ,048 &,- 24 \\
\hline gyors reagálás* & 157 & ,692 & $-2,550$ & ,011 &,- 26 \\
\hline
\end{tabular}


A hallgatók a már pályán levő pedagógusokhoz hasonlóan az elkötelezettséget tartották a legkevésbé fejleszthetőnek. Mindkét csoportban a kiegyensúlyozottság és az empátia van a 25. és a 24. helyen. A két legfontosabb tulajdonság, a pedagógusok szerint, a hitelesség és az empátia. Ezeket, különösen az empátiát kevéssé tartották fejleszthetőnek. A hallgatók hozzájuk képest jobbnak ítélték a kilátásaikat a fejlesztés tekintetében, mivel az empátiát kevésbé fontosnak, a hitelességet viszont fejleszthetőbbnek vélték. Mindkét tulajdonságról azt lehet mondani, hogy nagyon átfogó magatartásmintát írnak le, ezért is gondolhatták ezeket kevésbé fejleszthetőnek. Ugyanakkor a pszichológia-pedagógia képzés hangsúlyosan foglalkozik az önismerettel, ami a hitelességhez járulhat hozzá, és erőteljesen megjelenik a diákok személyes megismerésének fontossága is, ami az empátia alapja. Ezeket az eredményeket a képzés céljai szempontjából pozitívnak tekinthetjük.

Az önreflexió, a hitelesség, a gyors reagálás, az együttmüködési készség, a kultúrákra való nyitottság és az etikai elkötelezettség azok a területek, ahol a hallgatók nagyobb mértében feltételezték a fejlesztés lehetőségét. Tendencia szintü különbséget találtunk a hallgatók javára az új helyzetekhez való alkalmazkodás és a jól magyarázni tudás fejleszthetőségének megítélésében is.

A pedagógusképzés szempontjából kulcsfontosságú, hogy mit gondolunk a tanári tulajdonságok fejleszthetőségéről. Kifejezetten pozitív az önfejlesztés szempontjából, ha a hallgatók a fontos tulajdonságokról azt gondolják, hogy egyben fejleszthetőek is. Vizsgálatunk csak a végzés, illetve a pálya egy pillanatában vizsgálja az attitüdöt, kétségtelenül csak longitudinális vizsgálattal lehetne eldönteni, hogy a hallgatók hozzáállása a pályatapasztalatok alapján nem válik-e szintén pesszimistábbá. A pályakezdők pozitívabb hozzáállása a fejleszthetőség kérdéséhez mindenképpen jó alap lehet a további fejlődéshez. Ebben a hozzáállásban az önreflexió fejleszthetöségének kulcsszerepe lehet, amire a hallgatók a pedagógusoknál magasabb értéket, és számszerủen is az egyik legmagasabb értéket adták (átlag=4,03).

\section{Mennyiben fejlesztette a pedagógusképzés a tulajdonságokat?}

Mint az előzőekben láttuk, a 26 tulajdonság többségét, 16-ot azonosan ítélték meg a pedagógusok és a diákok fontosságuk szempontjából. Ahol különbséget találtunk, ott, egy kivételével, a diákok tartották fontosabbnak a tulajdonságokat. A pedagógusképzés fejlesztő hatásának megítélése szempontjából fontos, hogy mennyire tartják fejleszthetőnek a tulajdonságokat. Mivel az esetek kétharmadában erről is közel azonos a két csoport véleménye, ezért jól összemérhetőek a pedagógusképzés tényleges hatékonyságára vonatkozó vélemények. A hallgatók egy kivétellel minden esetben pozitívabban vélekedtek a képzésről, mint a pályán levő pedagógusok. Kilenc tulajdonságnál számottevő a javulás, további három esetben tendenciaszintü a különbség (3. ábra, 5. táblázat). 


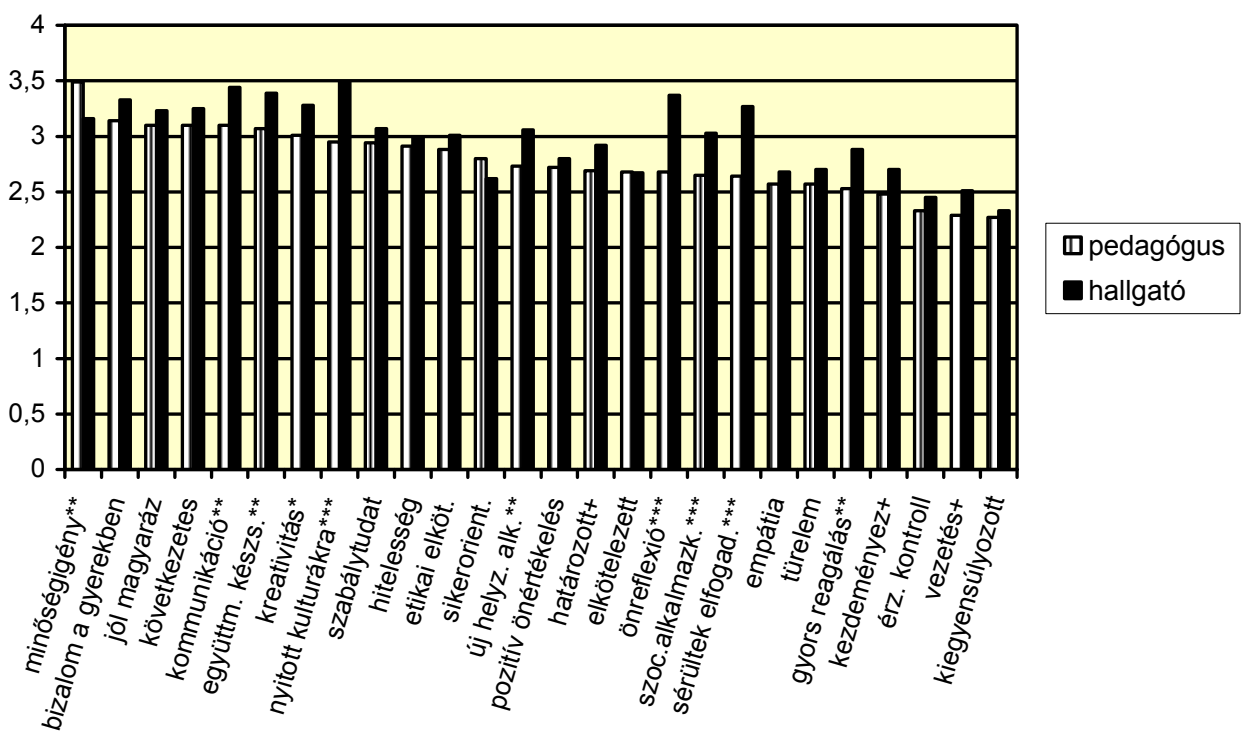

3. ábra: Milyen mértékben fejlesztette a tulajdonságokat a tanárképzés a pedagógusok és a hallgatók véleménye szerint?

5. táblázat: Mennyire fejleszthette a pedagógusképzés az adott tulajdonságokat a pedagógusok és hallgatók szerint? (Kétmintás t-próba)

\begin{tabular}{|c|c|c|c|c|c|}
\hline Tulajdonságok & $F$ & Szig. & $t$ & $\begin{array}{c}\text { Szig. } \\
\text { (2-oldalú) }\end{array}$ & $\begin{array}{c}\text { Átlag- } \\
\text { különbség }\end{array}$ \\
\hline önreflexió*** & 6,166 &, 013 & $-5,957$ & 000 &,- 69 \\
\hline szoc. alk.*** & 10,712 &, 001 & $-3,515$ & 001 &,- 37 \\
\hline új helyzethez alk.** & ,491 & ,484 & $-2,799$ & ,005 &,- 33 \\
\hline kezdeményez $^{+}$ & ,310 &, 578 & $-1,914$ &, 056 &,- 23 \\
\hline minőségigény** & 051 &, 821 & 2,878 & 004 & ,34 \\
\hline nyitott a kulturákra*** & ,483 & ,487 & $-4,204$ & ,000 &,- 54 \\
\hline vezetés $^{+}$ & 037 &, 847 & $-1,889$ & 060 &,- 22 \\
\hline sérültek elf. $* * *$ & 3,614 &, 058 & $-4,577$ & 000 &,- 63 \\
\hline együttm. készs. ${ }^{* *}$ & ,437 &, 509 & $-2,747$ & 006 &,- 32 \\
\hline kreativitás* & ,416 &, 520 & $-2,199$ &, 028 &,- 27 \\
\hline gyors reagálás** & , 183 & ,669 & $-2,905$ & 004 &,- 35 \\
\hline határozott $^{+}$ & 000 & ,983 & $-1,927$ & 055 &,- 23 \\
\hline kommunikáció** & ,037 & ,848 & $-2,917$ & ,004 &,- 35 \\
\hline
\end{tabular}


A minőségigény az egyetlen terület, ahol elmarad a jelenlegi képzés a korábbiaktól. A frissen végzettek relatív elégedettsége két szempont mentén rajzolódik ki. Az egyik terület a személyiség általánosabb szintü alkalmasságával kapcsolatos: kommunikációs készség, határozottság és a fejlődést elősegítő önreflexió. A másik tulajdonságcsokrot az alkalmazkodási képességgel, rugalmassággal címkézhetjük: szociális alkalmazkodás, új helyzethez alkalmazkodás, gyors reagálás, kreativitás, kezdeményezö- és együttműködési készség, vezetési képesség, kultúrákra való nyitottság, sérültek elfogadása.

Az eredményeink - úgy gondoljuk -, hogy okot adnak némi optimizmusra. A közbeszédben sokszor megfogalmazott általános elmarasztaló véleménnyel szemben a hallgatók határozottan jobb véleményt fogalmaznak meg a képzésről, mint a már pályán levő, korábban végzettséget szerzettek. Minek köszönhetőek ezek az eredmények? Az 111/1997-es kormányrendelet meghatározta a tanárképzés képesítési követelményeit. Ennek alapján széles körủ reformokat hajtottunk végre az ELTE-n, mint ahogy feltételezhetően minden tanárképzéssel foglalkozó intézményben is. A legvalószínübb magyarázat ezért véleményünk szerint a korábbinál színvonalasabb tanárképzés. Ezt bizonyítani longitudinális vizsgálatokkal kellene, amire nagy szükség is lenne, mert a 2004-ben indult bolognai tanárképzés a korábbiaknál még alapvetőbb reformokat jelentett. Ennek eredményeit objektív mutatók mentén szükséges megítélni.

A frissen végzett diákok tehát számos vonatkozásban elégedettebbek a képzéssel, mint a korábban végzettek. Ez örvendetes, de az elégedettség csak viszonylagos. Érdemes az attitűdskálák átlagértékeire is figyelnünk. A diákok esetében sem érte el az átlag egyetlen tulajdonság esetén sem a 3,5-es értéket az ötfokú skálán ( $1=$ egyáltalán nem, $3=$ =közepes mértékben, $5=$ teljes mértékben), ami azt jelzi számunkra, hogy ezeken a területeken a képzést tovább érdemes erősíteni.

Nézzük meg, hogy a hallgatók a saját elvárásaikhoz képest mennyire elégedettek, mik a képzés relatív erősségei és gyengeségei. A hallgatók relatív elégedetlenségét úgy határoztuk meg, hogy kivontuk az egyes tulajdonságok fontosságából a képzés által nyújtott fejlesztés mértékét. Ezt mutatjuk be a 4. ábrán.

A tulajdonságok rangsorában öt csoportot különíthetünk el (Friedman próba) abból a szempontból, hogy az igények és a tényleges képzés nyújtotta fejlesztés közt mekkora különbséget érzékelnek a hallgatók. Különbség van a kiegyensúlyozottságtól az érzelmi kontrollig terjedö öt tulajdonság és a hitelesség közt (Friedman $\mathrm{p}<0,05)$, a hitelesség és következetesség közti hat tulajdonság és az etikai elkötelezettség közt (Friedman p<0,05), az etikai elkötelezettségtől az önreflexióig terjedő nyolc tulajdonság és az együttmüködő készség közt (Friedman $p<0,01$ ), az együttmüködő készségtől a kultúrákra nyitottságig terjedő három tulajdonság és az utolsó négy tulajdonság közt (Friedman $\mathrm{p}<0,05)$. 


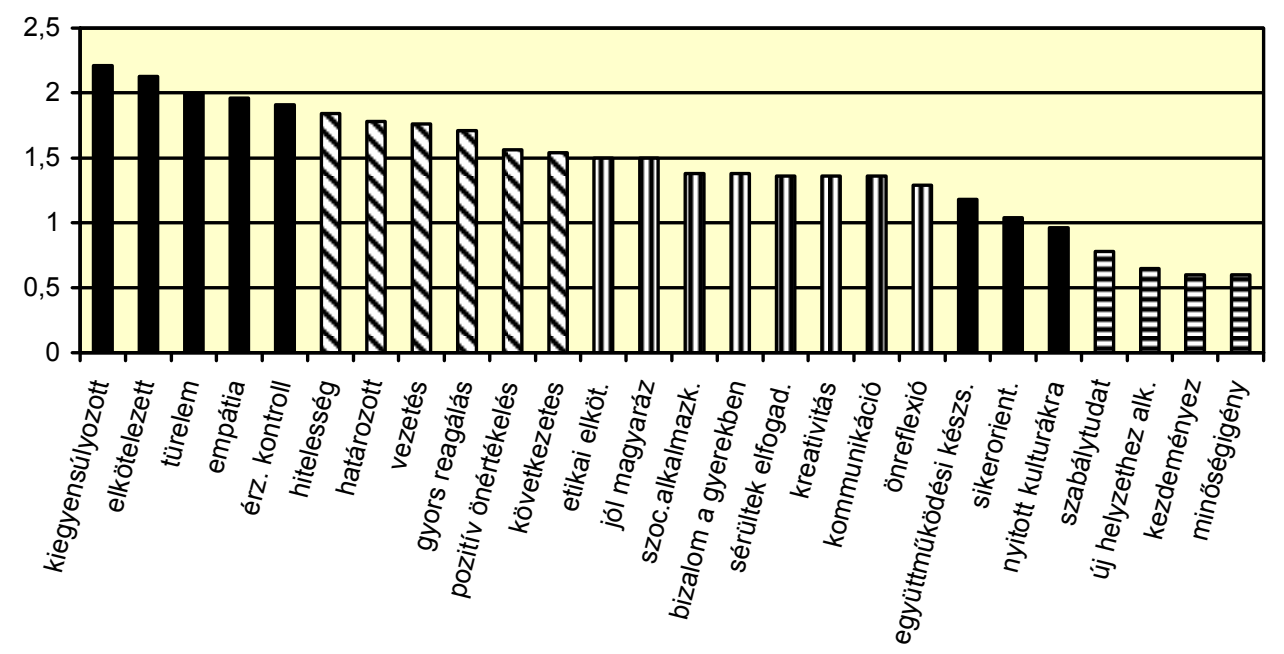

4. ábra: Elégedetlenség a pedagógusképzéssel a tulajdonság fontosságához képest (hallgatók adatai)

Legkevesebb hiányérzete a hallgatóknak a minőségigény, a kezdeményezőkészség, az új helyzetekhez alkalmazkodás és a szabálytudat kialakításával kapcsolatban van. Ezek közül a szabálytudat az a tulajdonság, amit nem is tartottak túl fontosnak, a többinél azt mondhatjuk, lényegében elégedettek a kapott képzéssel. A hallgatók éppen úgy a pszichés kiegyensúlyozottság és a szociális készségek (türelem, empátia, érzelmi kontroll) területével elégedetlenek leginkább, mint ahogy ezt korábban a pedagógusoknál láttuk, és a képzés adós marad a tanári pálya iránti elkötelezettség mélyítésének területén is.

Nézzük meg, mennyire fejlesztettek azok a tulajdonságok, amelyeket a hallgatók fontosabbnak ítéltek, mint a gyakorlatban dolgozók. A sérültek elfogadása és a kultúrákra való nyitottság, melyek fontosságát a hallgatók szemében azzal magyaráztuk, hogy a hallgatók tudatossága ezeken a területeken nagyobb, valóban hatékonyan fejlesztett területek. Ezeket a képzés viszonylag jól fejlesztette, hiszen az elégedetlenségi rangsor második felében, a 16. és 22 . helyen találhatóak. A pályakezdés kihívásaiként értelmezett tulajdonságok, a határozottság, a vezetési képesség és a kezdeményező készség közül a két előbbi a rangsor második blokkjában, a 7. és a 8. helyen, a kezdeményezö képesség viszont, mint kiemeltük, a 25. helyen áll. A kreativitás és gyors reagálás a 17. és a 9. helyen szerepel, vagyis a harmadik (középső) blokk és második blokk tagja.

A 4. ábrán bemutatottak úgy véljük, beszédesen jelölik ki a tanárképzés javításához szükséges további feladatokat. Egyrészt érdemes még több időt és főként aktív tevékenységet szentelni az önismeret, az önkontroll és a szociális készség fej- 
lesztésnek, másrészt a pályakezdéskor nehézséget jelentö területeknek, a gyerekcsoportokkal való bánásmódnak, a vezetés tanulásának és a minél változatosabb helyzetek kipróbálásának, hogy fejlődjön a gyors reagálás képessége is.

\section{Mi segitett a pedagógus pályára való készülésben?}

A pedagógusok válaszai alapján már korábban is kaptunk támpontokat arra, hogy a hatékony fejlesztés konkrétan milyen oktatási tevékenységeket jelenthet. A pedagógusok a valódi iskolai tapasztalatokat tartották a leghasznosabbnak, és ezt követték a pedagógusképzés gyakorlati elemei.

A hallgatók és a gyakorló pedagógusok válaszait összehasonlítva tartalmilag alig találunk különbségeket. Összességében megerősödik a fent vázolt kép, hogy a valódi pedagógiai tapasztalatok (a hallgatók esetén a képzés részeként szerzett tanítási gyakorlat) hatékonysága kiemelkedik a többi közül (5. ábra).

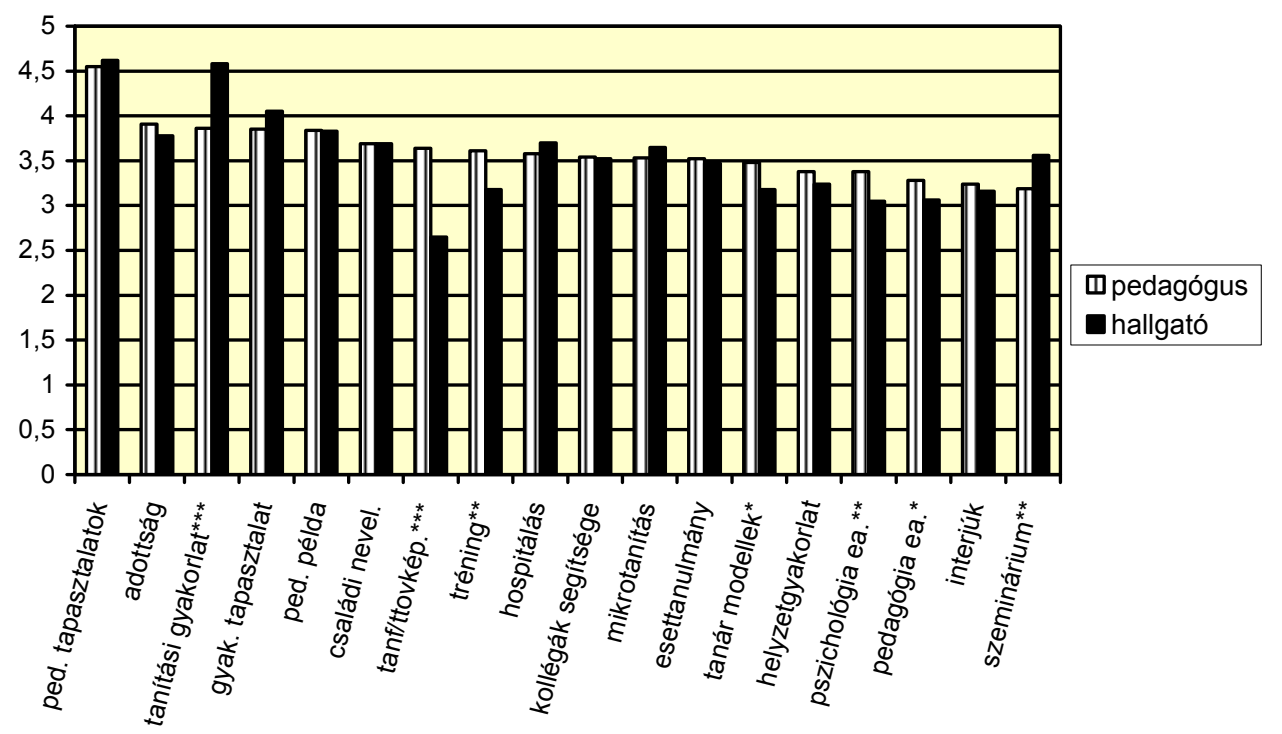

5. ábra: Mi segített a pedagóguspályára való készülésben?

A saját képzésükkel kapcsolatban a hallgatók a leghatékonyabb módszernek a tanítási gyakorlatot tartották. Lényegesen hatékonyabbnak ítélték ezt, mint a már pályán levők. Mivel általában a képzésről hasonlóan vélekedett a két csoport, úgy véljük, hogy a kapott eredmény alapján határozottan megfogalmazhatjuk elismerésünket a gyakorló iskolák vezetőtanárainak munkájával kapcsolatban. Ez az eredmény aláhúzza az MA képzés utolsó félévében iskolában, mentortanár vezetésével végzett gyakorlat jelentőségét, amelyben a bolognai képzés nappali tagozatos hallgatói a 2011-es őszi félévben vesznek részt először. Ez a gyakorlat egyesíti remé- 
nyeink szerint a tanítási gyakorlat és az ugyancsak nagyra értékelt (tanárként szerzett) pedagógiai tapasztalat előnyeit, ugyanis védett környezetben nyújt valódi tapasztalatokat.

6. táblázat: Különbségek a pedagógusok és hallgatók közt annak megítélésében, hogy mi segített a pedagógus pályára való készülésben. (Kétmintás t-próba)

\begin{tabular}{|l|r|r|r|c|c|}
\hline \multicolumn{1}{|c|}{$\begin{array}{c}\text { Segítségek } \\
\text { a felkészülésben }\end{array}$} & $F$ & Szig. & $t$ & $\begin{array}{c}\text { Szig. } \\
\text { (2-oldalú) }\end{array}$ & $\begin{array}{c}\text { Átlag- } \\
\text { különbség }\end{array}$ \\
\hline tanítási gyakorlat*** & 17,506 &, 000 & $-7,456$ &, 000 &,- 71 \\
\hline pszichológia elöadás** & 3,844 &, 051 & 2,746 &, 006 &, 32 \\
\hline pedagógia elöadás* & 5,143 &, 024 & 1,959 &, 051 &, 22 \\
\hline szeminárium** &, 338 &, 561 & $-3,270$ &, 001 &,- 38 \\
\hline tréning** &, 030 &, 863 & 3,097 &, 002 &, 43 \\
\hline tanár modellek* &, 772 &, 380 & 2,285 &, 023 &, 29 \\
\hline tanfolyam/tov. képzés*** & 41,994 &, 000 & 5,569 &, 000 &, 99 \\
\hline
\end{tabular}

A másik kiemelkedő terület, ami a felkészülést segítette, a már pedagógusi pozícióban végzett tanítás, illetve az iskolán kívüli pedagógiai tapasztalatok diákokkal. A hallgatók is jelentős arányban rendelkeznek ilyen tapasztalatokkal, csupán 12,5 százalékuk nyilatkozik úgy, hogy ilyen tapasztalatuk egyáltalán nem volt. Ennek hatékonyságát egyaránt nagyra értékelték a már gyakorlatban dolgozók és a kezdők is.

A következő terület, amelynek kapcsán hallgatóink nagyobb hatékonyságról számolnak be, a szemináriumok. Ezt a képzési formát meglehetősen hatékonynak tartották az ELTE tanárképzésének résztvevői. A szemináriumok mind a pedagógiai, mind a pszichológia területén gyakorlatcentrikusak, interaktívak, s ennek hatékonyságát igazolják vissza a válaszok.

A végzős hallgatók a pedagógusokhoz képest kevésbé tartották hatékonynak a pszichológia és pedagógia előadásokat, magukat az egyetemi oktatókat, mint modelleket és a tréningeket. Mi lehet ezek oka?

A pedagógusok a pszichológia előadásokat hatékonyabbnak találták, mint a pedagógia előadásokat, az ELTE diákjai az előadásokat összességében is a legkevésbé hatékonynak ítélik. Nincs kifejezetten rossz véleményük, csupán „közepes”. Ezt az eredményt árnyalja, ha összevetjük az alább tárgyalt eredményekkel (6. és 9. ábra), melyekből az fogjuk látni, hogy általában a képzés és így az előadások maguk is az elméleti tudás és szemlélet közvetítésében hatékonyabbak, mint a gyakorlati tudás átadásában.

A tanármodellek hiánya úgy véljük, összefügghet azzal, hogy a kreditrendszernek köszönhetően a képzésben újabban nincsenek stabil tanulói csoportok, a taná- 
rok és a diákok több félévig tartó közös munkája is ritka kivételnek számít. Ez határozott veszteség a jelenlegi képzésben. Bennünket, képzőket is foglalkoztat az a kérdés, hogy miként lehetne a jelenlegi képzési keretek között élő diákközösségeket és jól müködő tanár-diák viszonyt kialakítani.

A tréningek megítélésénél azt láthatjuk, hogy a pedagógusképzés vizsgált elemei közül ennek a szórása a legnagyobb $(\mathrm{s}=1,22)$, vagyis itt a diákok közt viszonylag nagy a nézetkülönbség. Ez, úgy véljük, két okra is visszavezethető. Egyrészt számolnunk kell azzal, hogy jelenleg még a tréningek közt jelentősek a különbségek, vannak nagyobb hatékonyságú és kevésbé sikeres órák, másrészt a diákok is eltérően fogadják a tréningeket. Az eredmények a minőségjavítás szempontjából jelzés értékủek, mutatják, hogy mind a tréningeken alkalmazott módszereken, mind a diákok egyéni igényeinek megfelelő tréningtípus választásának segítésén érdemes dolgozni, mert gyakran találkozunk azzal, hogy a diákok választásában az óra megfelelö időpontja a domináns szempont.

A tanártovábbképzés mellett a hallgatók által látogatott tanfolyamok hatékonyságát is megítéltettük. A hallgatóink viszonylag nagy arányban vesznek részt fizetett képzéseken, ezeket önszorgalomból az egyetemmel párhuzamosan végezték. Az 5. ábrán a tanártovábbképzéseket és egyéb tanfolyamokat együtt ábrázoltuk. Azt láthatjuk, hogy míg a kifejezetten pedagógusoknak készült továbbképzésekről a gyakorlatban dolgozók visszajelzése jó, addig a hallgatók nem találnak, (vagy nem is keresnek) a tanárképzésben jól hasznosítható tanfolyamokat.

Érdemes aláhúznunk azt a tényt, hogy a pedagógiai tapasztalatok szerepét mindkét csoport jelentősebbnek ítéli, mint a személy számára befolyásolhatatlan tényezőket, például a családi nevelést, a saját iskoláskori tanáraik által nyújtott pedagógus példákat vagy a személyes adottságaikat. Ezt fontos és pozitív szemléletbeli jellemzőnek tartjuk, ti. a válaszban a pedagógusoknak saját nevelhetőségükről való pozitív állásfoglalása is megjelenik.

\section{A tanári feladatokra való felkészités hatékonysága}

Az utolsóként tárgyalt kérdésben az egyes tanári feladatok szempontjából vizsgáljuk, hogy a képzés ezeket milyen mértékben tudta nyújtani. Emellett megvizsgáljuk, hogy a hallgatók elégedetlenségének mértékében, vagyis az általuk elvárt és a ténylegesen kapott felkészítés között milyen különbségek vannak.

A pedagógusok és a tanárjelöltek véleményének összehasonlítását a pedagógusképzés által nyújtott felkészítésről a 6 . ábrán mutatjuk be, a szignifikáns különbségeket a 7. táblázat tartalmazza. 


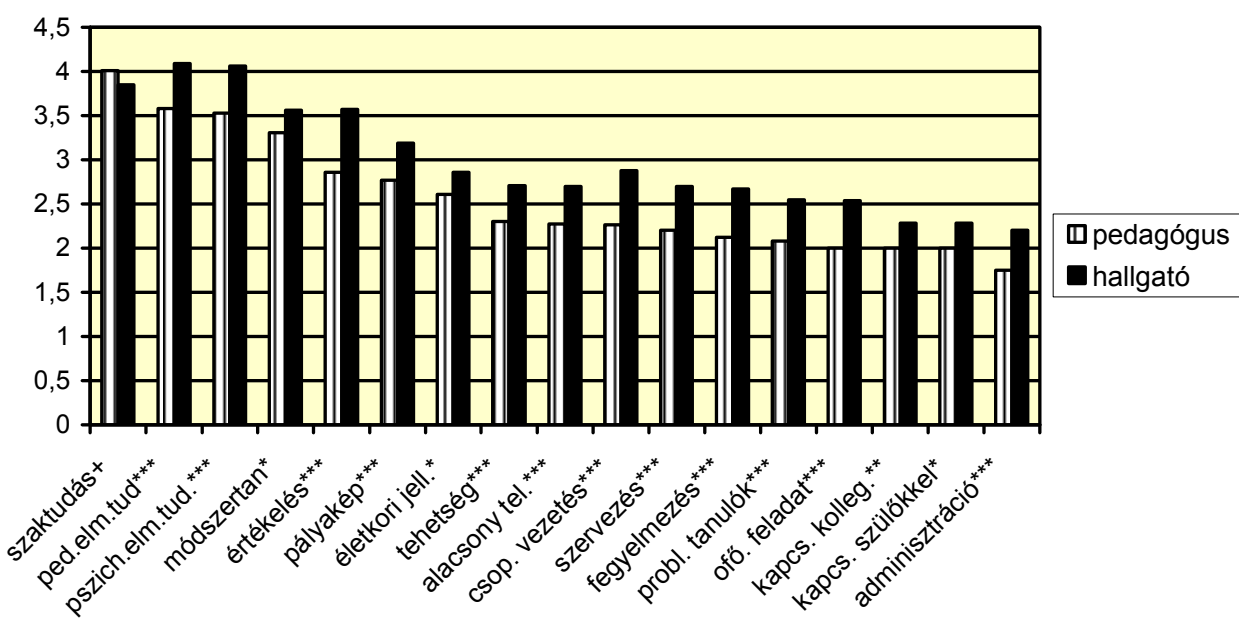

6. ábra: Mennyire nyújtotta ezeket az ismereteket a képzés?

7. táblázat: Különbségek a pedagógusok és hallgatók közt annak megítélésében, hogy a képzés mennyire fejlesztette öket az egyes kompetenciaterületeken. (Kétmintás t-próba)

\begin{tabular}{|c|c|c|c|c|c|}
\hline $\begin{array}{c}\text { A kompetenciaterületek } \\
\text { fejlesztése }\end{array}$ & $F$ & Szig. & $t$ & $\begin{array}{c}\text { Szig. } \\
\text { (2-oldalú) }\end{array}$ & $\begin{array}{c}\text { Atlag- } \\
\text { különbség }\end{array}$ \\
\hline szaktudás $^{+}$ & 5,550 & ,019 & 1,875 & 062 & , 16 \\
\hline módszertan* & 1,706 & ,192 & $-2,298$ & ,022 &,- 26 \\
\hline pedagógiai elm. tud $* * *$ & 12,104 & 001 & $-5,044$ &, 000 &,- 50 \\
\hline pszichológiai elm. tud.*** & 14,552 &, 000 & $-5,299$ & 000 &,- 53 \\
\hline pályakép*** & ,344 & ,558 & $-3,739$ & 000 &,- 43 \\
\hline életkori jellemzők* & 2,311 &, 129 & $-2,173$ &, 030 &,- 25 \\
\hline tehetség*** & 1,645 & 200 & $-3,415$ & 001 &,- 41 \\
\hline alacsony teljesítmény*** & 4,618 & ,032 & $-3,787$ &, 000 &,- 43 \\
\hline problémás tanulók ${ }^{* * *}$ & 103 & ,749 & $-4,175$ & ,000 &,- 47 \\
\hline csop. vezetés*** & 001 & ,974 & $-5,210$ &, 000 &,- 62 \\
\hline fegyelmezés*** & ,337 & ,562 & $-4,925$ & 000 &,- 55 \\
\hline osztályfönöki feladat*** & 2,709 &, 101 & $-4,500$ &, 000 &,- 53 \\
\hline értékelés*** & 4,722 & ,030 & $-6,638$ & ,000 &,- 71 \\
\hline kapcsolat kollégákkal ** & 1,164 & 281 & $-2,573$ &, 010 &,- 28 \\
\hline kapcsolat szülökkel* &, 330 &, 566 & $-2,435$ &, 015 &,- 28 \\
\hline szervezés*** & 1,894 &, 169 & $-4,265$ & 000 &,- 50 \\
\hline adminisztráció $* * *$ & 6,362 & 012 & $-3,861$ &, 000 &,- 45 \\
\hline
\end{tabular}


A hallgatók egy témakör, a szaktudás kivételével valamennyi vizsgált területen szignifikánsan jobbnak ítélik meg a pályára való felkészítésüket, mint a pedagógusok. A szaktudás területén, amely egyébként mindkét csoport részéről az egyik leghatékonyabbnak ítélt terület, a korábbi képzés többet nyújtott a pedagógusoknak, bár ez a különbség is csak tendencia szintü $(\mathrm{p}<0,10)$. További vizsgálatot igényelne, hogy ez miért van így. Itt figyelembe kell vennünk azt, hogy a mintánkban a pályakezdők túlnyomó többsége a bölcsész szakterületekhez tartozik, a természettudományos tanárképzésről nincs kellő információnk. Érdemes lenne információkat gyüjteni arról, hogy milyen tekintetben marad el a most végzők tárgyi tudása a korábbiaktól. Ugyanakkor azt is érdemes kiemelnünk, hogy a diákok véleménye alapján nem ez a sürgető probléma a tanárképzésben. Az egyik legjobb értéket ugyanis a ténylegesen kapott felkészítés vonatkozásában a szaktudás kapta mind a tanárképzés többi eleméhez viszonyítva, mind a szakmai színvonal iránt támasztott hallgatói igényekhez képest.

Ha csak saját képzésünk eredményeit akarnánk nyugtázni, akkor az itt kapott eredményekkel méltán lehetnénk elégedettek, többet nyújtottunk, mint a korábbi képzések. Érdemes azonban a kérdést a hallgatók igényei felől is mérlegre tenni.

\section{A tanárképzéssel kapcsolatos igények}

A tanárképzéssel szemben támasztott igények tekintetében a pedagógusok és a hallgatók véleménye nagymértékben egyezik (7. ábra, 8. táblázat).

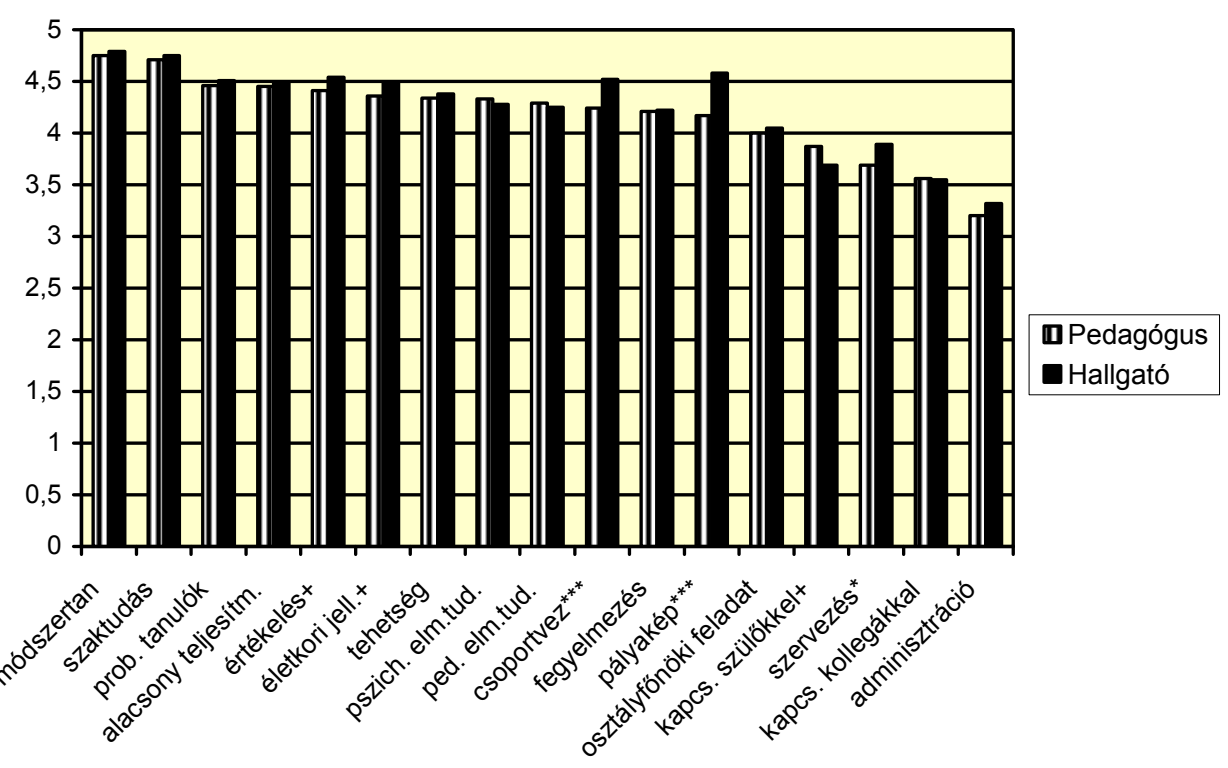

7. ábra: Igény a pedagógusképzés iránt 
8. táblázat: Mennyire kellene, hogy fejlessze a pedagógusképzés a pedagógusok és hallgatók szerint? (Kétmintás t-próba)

\begin{tabular}{|l|c|c|c|c|c|}
\hline \multicolumn{1}{|c|}{$\begin{array}{c}\text { Igényelt } \\
\text { kompetenciaterületek }\end{array}$} & $F$ & Szig. & $t$ & $\begin{array}{c}\text { Szig. } \\
\text { (2-oldalú) }\end{array}$ & $\begin{array}{c}\text { Átlag- } \\
\text { különbség }\end{array}$ \\
\hline pályakép*** $^{\text {életkori jellemzök }}{ }^{+}$ & 3,644 &, 057 & $-5,281$ &, 000 &,- 40 \\
\hline csoportvezetés*** $^{*}, 158$ &, 692 & $-1,904$ &, 058 &,- 13 \\
\hline értékelés $^{+}$ & 2,403 &, 122 & $-3,809$ &, 000 &,- 27 \\
\hline kapcsolat szülökkel $^{+}$ & 4,448 &, 036 & $-1,923$ &, 055 &,- 13 \\
\hline szervezés* $^{*}$ & 4,092 &, 044 & 1,829 &, 069 &, 19 \\
\hline
\end{tabular}

Három területnek szentelnének a hallgatók nagyobb teret, ezek a pályakép közvetítése, csoportvezetés és szervezés. Tendencia szinten még eltérést találunk az életkori jellemzők ismerete és az értékelés terén is. Itt is erőteljesebb a hallgatók igénye. A szülőkkel való kapcsolat kialakítása az egyetlen terület, ahol tendencia szinten a pedagógusok igénye nagyobb.

A pályaképpel kapcsolatos ismeretek közvetítését a képzés keretében szintén fontosabbnak érzik a hallgatók, mint a pályán levők, de ha megnézzük a 7. ábrát, látjuk, hogy nem elégedetlenek a képzéssel (átlag: 3,20). Inkább azt mondhatjuk, hogy jobban látják ennek a témának a szükségességét.

A másik igényelt terület a csoportvezetés és az ehhez gyakran szorosan kapcsolódó szervezés. Ezzel kapcsolatban azt érdemes aláhúzni, hogy a csoportvezetés terén a képzés által nyújtott mértéket is kevésnek érzik (átlag: 2,88 ). Ha végiggondoljuk a képzés gyakorlatát, akkor be kell látnunk, hogy ez reális kritika, úgy tünik, sikerült nekik megtanítani, hogy a csoportvezetés fontos a diákokkal való munkában, csak azzal maradtunk adósak, hogy igazi feladathelyzetbe hozzuk öket, ahol, a csoporttal kell dolgozni. A tanítási gyakorlat ugyan csoporttal való bánásmód, de védett közegben, a vezetőtanár a csoport szintjén könnyen beavatkozik, nincs igazi kockázata, s talán tere sem a csoportvezetésnek.

\section{Elégedettség és elégedetlenség a pedagógusképzéssel kapcsolatban}

A pedagóguspálya gyakorlásához szükséges felkészültség, illetve a tanári kompetenciák lényeges elemeit két vonatkozásban vizsgáltuk, egyrészt, hogy a felkészítést milyen mértékben igénylik a megkérdezettek, másrészt, hogy ténylegesen a képzés mennyire nyújtotta ezeket. Ilyen módon az elégedettség és az elégedetlenség mértékével kapcsolatban is kaptunk információkat.

A pedagógiai elméleti tudás iránti igény és a ténylegesen nyújtott képzés közt csak tendenciaszintü különbség van, viszont az összes többi vizsgált területen szig- 
nifikánsan többet várnak a diákok, mint amennyi felkészítést a képzés során kaptak. (Összetartozó mintáknál t-próba. Részleteiben a t-próba értékeit nem közöljük, mert egy terület, a pszichológiai elméleti tudás kivételével, ahol a szignifikancia szint $\mathrm{p}<0,05$, minden különbség $\mathrm{p}<0,001$ szinten szignifikáns).

Az elégedetlenség mértékét a hallgatók által igényelt mérték és a tanárképzés által ténylegesen nyújtott felkészítés különbségéből számoltuk ki (8. ábra).

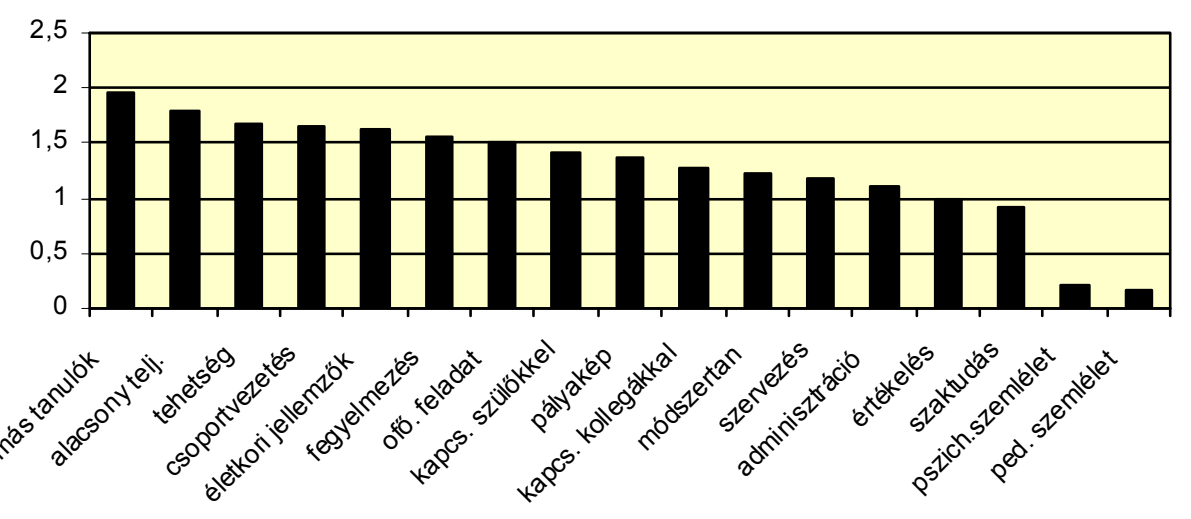

8. ábra: Mennyire elégedetlenek a pedagógusképzéssel (hallgatók véleménye)

A hallgatók hasonlóan a pedagógusokhoz (N. Kollár, 2008) több ponton fogalmaznak meg hiányosságokat. Két olyan terület van, ahol a képzés megközelítette azt a szintet, amit a hallgatók várnak, ez a pszichológiai-pedagógiai szemlélet nyújtásának területe. A szaktudás és a pedagógiai értékelés még az a két terület, ahol leginkább felkészültnek érzik magukat, bár ebben már jelentős fejlődést is elképzelhetönek tartanak.

Igazi problémát - ugyanúgy, mint a pályán levőknél - a magatartási problémákkal küzdő tanulók jelentik, valamint az átlagtól eltérő teljesítmény, legyen az alacsony vagy átlag feletti. Ebbe, az egyéni, a differenciált bánásmód kérdéskörébe tartozó problémacsokorba sorolhatjuk az életkori jellemzőkhöz alkalmazkodó oktatást is, amiben szintén felkészületlennek érzik magukat a diákok. A másik fókuszpont, ahol a képzést erösíteni érdemes, a tanulócsoportokkal való bánásmód, a csoportvezetéstől a fegyelmezésen át az osztályfönöki feladatokig.

A szülőkkel való kapcsolat is problémát jelent. A 6. ábrán láthatjuk, hogy a hallgatók ezen a területen is kaptak a képzés során támpontokat, de ebben sem érzik kellő mértékben otthon magukat. A kezdő pedagógusoknak életkoruk miatt sem könnyü ez a terület, hiszen saját szüleik korosztályával kell együttműködni, az eddigiektől alapvetően különböző pozícióban. Hasznos lenne erre a kérdéskörre nagyobb figyelmet szentelni, talán éppen a tréning az a képzési forma, ahol érdemes lenne ezzel a témával is foglalkozni. 
A fentiekben részletesen bemutattuk, hogy a 2007-2008-as tanévben az ELTE-n tanári diplomát szerző hallgatók elégedettebbek a képzésükkel és abszolút számokban is kisebb az elégedetlenségük, mint a pályán levőké. A vizsgált területek közül csupán a szaktudásuk az, amelyben a különbség fordított irányú, a diákjaink elégedetlenebbek (9. ábra).

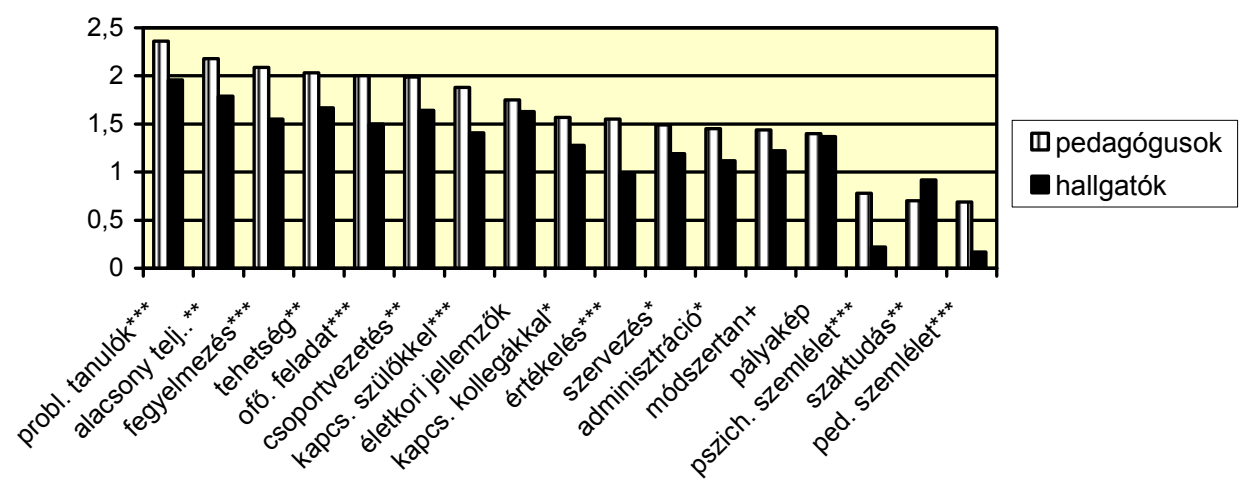

9. ábra: Mennyire elégedetlenek a pedagógusképzéssel?

9. táblázat: Pedagógusok és hallgatók közti különbségek a tanárképzéssel szemben támasztott igények terén. (Kétmintás t-próba)

\begin{tabular}{|l|r|r|c|c|c|}
\hline \multicolumn{1}{|c|}{$\begin{array}{c}\text { Igényelt } \\
\text { kompetenciaterületek }\end{array}$} & $F$ & Szig. & $t$ & $\begin{array}{c}\text { Szig. } \\
\text { (2-oldalú) }\end{array}$ & $\begin{array}{c}\text { Átlag- } \\
\text { különbség }\end{array}$ \\
\hline Szaktudás** & 1,360 &, 244 & $-2,596$ &, 010 &,- 22 \\
\hline módszertan $^{+}$ &, 760 &, 384 & 1,870 &, 062 &, 22 \\
\hline pedagógiai szemlélet*** &, 525 &, 469 & 4,354 &, 000 &, 52 \\
\hline pszichológiai szemlélet*** & 2,054 &, 153 & 4,978 &, 000 &, 56 \\
\hline tehetség** &, 798 &, 372 & 2,797 &, 005 &, 36 \\
\hline alacsony teljesítmény** & 1,645 &, 200 & 2,978 &, 003 &, 39 \\
\hline problémás tanulók*** &, 121 &, 728 & 3,247 &, 001 &, 41 \\
\hline csoportvezetés** $^{1,188}$ &, 276 & 2,599 &, 010 &, 34 \\
\hline fegyelmezés*** & 4,693 &, 031 & 3,686 &, 000 &, 54 \\
\hline osztályfönöki feladat*** &, 812 &, 368 & 3,659 &, 000 &, 50 \\
\hline értékelés*** & 8,785 &, 003 & 4,682 &, 000 &, 57 \\
\hline kapcsolat kollegákkal* &, 087 &, 768 & 2,284 &, 023 &, 29 \\
\hline kapcsolat szülökkel*** &, 051 &, 822 & 3,475 &, 001 &, 47 \\
\hline szervezés* &, 011 &, 918 & 2,488 &, 013 &, 30 \\
\hline adminisztráció* &, 149 &, 700 & 2,468 &, 014 &, 33 \\
\hline
\end{tabular}


A vizsgált 17 terület közül 14-ben az ELTE frissen végzett hallgatói jobban felkészítettnek érzik magukat, mint a már pályán levők. Két terület van, ahol a mi hallgatóink elégedettségének mértéke nem különbözik a pályán levőkétöl. Az egyik terület a pályaképpel kapcsolatos tudás, amelynek kapcsán korábban azt láttuk, hogy ebben a hallgatók igénye szignifikánsan nagyobb, mint a korábban végzetteké - vagyis a nyújtott képzés ezen a területen is jobb, csak az igények nőttek. A másik terület a diákok életkori jellemzöinek ismerete, ezzel kapcsolatban azt mondhatjuk, hogy érdemi elörelépést nem sikerült tenni a bolognai képzés előtti tanárképzésünkben.

A különbségeket részleteiben is vizsgálva azt láthatjuk, hogy a kitüntetetten fontos területek, a problémás tanulókkal, átlag alatt és átlag felett teljesítők, sőt a csoporttal való bánásmód (vezetés, fegyelmezés, osztályfőnöki feladatok) terén is komoly elörelépés mérhető a képzés hatékonyságában (9. táblázat). Ugyanakkor ezek azok a területek, ahol a képzésnek további feladatai vannak. Ezeket mind a diákok, mind a gyakorló pedagógusok szerint gyakorlati képzéssel, minél életszerübb pedagógiai tapasztalatok nyújtásával lehet hatékonyabbá tenni. A különböző módszerek hatékonyságával kapcsolatban azt mondhatjuk, hogy még a legkevésbé eredményesnek talált módszer - az előadás sem eredménytelen, csak „elég van belőle". A módszerek minél hatékonyabbak, annál költségesebbek, hiszen idő, tanári kapacitás és gyakorló terep igényesek. Ezért azt érdemes mérlegelni, hogy a képzésben hol és milyen arányban használjuk a szemináriumot, tréninget, a különbözö terepen való tapasztalatszerzést és az iskolai gyakorlatot. Ez utóbbi a hospitálásokkal kezdődhet és a tényleges tanítási tapasztalatoknál ér véget.

Fontos visszajelzés számunkra, hogy a szemináriumaink a diákok szerint a tanulás fontos terepei. Dolgoznunk kell azzal az információval is, hogy a tréningek fogadtatása, ha összességében meg is haladja a közepes (3-as) értéket, szórása a nagyon pozitívtól egészen az elutasításig terjed.

Egyetlen kompetenciaterület van, ahol a mi hallgatóink elégedetlenebbek, mint a pályán levők, ez a szaktudás területe. Szakmai szempontból a hallgatók kevésbé érzik felkészültnek magukat, mint a pályán levők. Ez az eredmény jelzésértékü, ugyanakkor elhamarkodott lenne azt a következtetést levonni, hogy a hallgatók felkészületlenek szakmailag, mivel a diákok által leginkább igényelt területek a módszertani tudás (lásd szakmódszertan) és a szakmai tudás (7. ábra). A képzés által leginkább nyújtott három terület közt is szerepel a szaktudás (6. ábra). Vagyis azt mondhatjuk, hogy a hallgatók leginkább szakmai szempontból felkészültek, pályakezdőként azonban a szakmai felkészültségük hiányosságait is érzik. A 8 . ábrát szemlélve azt a következtetést vonhatjuk le, hogy a jelenlegi tanárképzésben a felkészítés fö hiányosságai a tanulókkal való egyéni bánásmód, különösen a sajátos nevelési igényü tanulók kezelése terén vannak. 


\section{Zárszó}

A képzés hatékonyságának mérését a bolognai reform munkálatai során végeztük, a kétciklusú képzésre való áttérés és az MA szintü tanárképzés szakmai megalapozása érdekében. Célunk ezért ezzel a vizsgálattal elsősorban nem a képzés hatékonyságának mérése, hanem a hallgatói igények felmérése volt. Abból indultunk ki, hogy a képzés megújításához a pálya által támasztott igényekhez kell igazodnunk. Ezért fordultunk mind a pályán levő pedagógusokhoz, mind a végzős diákokhoz annak felmérésére, hogy melyek a felkészítésben erősítendő területek. A felmérés időpontja óta lezajlott az MA szintü tanárképzés bevezetése. A jelen vizsgálat tanulságaira támaszkodva az új képzésben számos tartalmi és módszertani változást hajtottunk végre. Ezek tartalmi részletei egy frissen megjelent tanulmánykötetben elérhetőek (N. Kollár, 2011; Rapos, 2011).

A tanárképzésben, különösen napjainkban, amikor a képzés struktúrája és tartalma alapvető változásokon megy keresztül és várhatóan a közeljövőben még jelentősen átalakul, feltétlenül kívánatosnak tartjuk a szisztematikus hatásmérést, a bemeneti és kimeneti változók, emberibben szólva a diákok jellemzőinek képzés előtti és a képzés befejezésekor mérhető értékeinek nyomon követését nem csupán az ELTE gyakorlatában, de országos méretekben is. Ez szilárd alapot biztosíthatna a fejlesztés további útjának kijelölésében, melyhez a képzésben részt vevő szakterületek szoros együttmüködése és nem utolsó sorban a diákokkal való közös gondolkodás is szükséges.

\section{Irodalom}

Darling-Hammond, L., Berry, B., Thoeson, A.: Does Teacher Certification Matter? Evaluating the Evidence. Educational Evaluation and Policy Analysis, Vol. 23, No. 1. (Spring, 2001) $57-77$.

Goldhaber D. D., Brewer D. J.: Does Teacher Certification Matter? High Scool Teacher Cerification Status and Student Achivement. Educational Evaluation and Policy Analysis, Vol. 22, No. 2. (Summer, 2000) 129-145.

http://www.tda.gov.uk/partners/datasurveys/nqtsurvey/nqtsurvey2007.aspx letöltve 2007.09.04.

Margiotta, U. (ed. 2010): European Teacher Education Achievments and Challenges. A joint curriculum development in Erasmus LLL EMETT project. Budapest, Copenhagen, Innsbruck, Krakow, Nantes, Venice, Vilnius, Formazione \& Insegnamento, 240.

N. Kollár Katalin (2008): Pedagógusok pályaképe, a tanárképzéssel való elégedettségük és nehézségeik. Pedagógusképzés, 4. sz. 7-34.

N. Kollár Katalin (2011): A bolognai tanárképzés jellemzői a pszichológia tárgyak oktatásának szemszögéből. In: Baumstark Beáta - Gombócz Orsolya - Hunyady György (szerk.): A tanárképzés 2010-2011 fordulóján. ELTE Eötvös Kiadó, Budapest, 81-112. 
Rapos Nóra (2011): A szakmai professzionalizmusra alapozó képzés, pedagógiai tárgyak a tanári modulban. In: Baumstark Beáta - Gombócz Orsolya - Hunyady György (szerk.): A tanárképzés 2010-2011 fordulóján. ELTE Eötvös Kiadó, Budapest, 113-129.

Rots, I., Aelterman, A., Vlerick, P., Vermeulen, K. (2007): Teacher education, graduates' teaching commitment and entrance into the teaching profession. Teaching \& Teacher Education, 23. 543-556.

Suplicz Sándor (2007): A pedagógusok sikeressége szempontjából fontos jellemzők diákvélemények tükrében. Alkalmazott pszichológia, 1. sz. 116-129. 